\title{
MUDHARABAH FINANCING SUPERVISION OF ISLAMIC BANKING IN INDONESIA
}

\author{
Bagas Heradhyaksa, RuzianMarkom \\ Faculty of Law, Universiti Kebangsaan Malaysia \\ bagasemai1123@gmail.com
}

\begin{abstract}
The regulation in Indonesia states that the supervision of mudharabah financing is the right of Islamic bank. The Regulation of Indonesian Bank number 7/46/PBI/2005 section 6 subsection C and in The Circular Letter of Indonesian Bank number 10/14/Dpbs states that the supervision is done by reviewing and requesting evidence from customer's business result report without being given more detailed about the procedure of conducting mudharabah financing supervision. The purpose of this research is to analyze regulation that regarding the mudharabah financing supervision inIslamic banking. The methodology used in this research is empirical juridical method. We applied the method by comparing between the existing regulations with the reality that occurred in the field. This study found that a more detailed regulation regarding supervision of mudharabah financing was needed. This is so that the process of monitoring mudharabah financing has a strong legal basis and standard among Islamic bank. Moreover, the customer can also understand the steps that should be taken in the implementation of mudharabah financing supervision.
\end{abstract}

Keywords: financing, mudharabah, Islamic banking, supervision.

\section{Introduction}

Conventional banking in channeling funds to customers is always in the form of money which is then up to debtor customers to use it. Limitations only refer to the applicable positive legal provisions. Whereas in Islamic Banking banks usually provide financing in the form of provision of tangible assets, both based on the concept of buying and selling, leasing, and profit sharing. As such, transactions that occur in Islamic Banking are transactions that are free of usury or interest because there are always transactions of underlying transactions, namely business or commercial transactions that legitimize an addition of wealth fairly. ${ }^{1}$

Fund disbursement in the form of financing has several Islamic contracts that can be used as described in the provisions of section 3 subsection B of Bank Indonesia Regulation Number 9/19/PBI/2007 which states that "In the form of funding disbursement activities, among others, mudharabah agreement, musyarakah, murabahah, salam, istishna ', ijarah, ijarahmuntahiyabittamlik and qardh"

Financing in Islamic Banking based on the profit sharing contract places the bank as the funder. Therefore, the bank has the right to get the profit sharing as much as the ratio to income or

\footnotetext{
${ }^{1}$ Rachmadi Usman. Produkdan Akad Perbankan Syariah di Indonesia (Bandung: Citra Aditya Bakti, 2009$), 173$.
} 
profit obtained by the business owner (mudhorib). Whereas if the bank only acts as a liaison between the entrepreneur and the customer, he is entitled to a fee.

One of the most widely used financing contracts in Islamic Banking is the mudharabah contract. Mudharabah is a form of cooperation between two or more parties in which the owner of the capital (shahibul mal) entrusts a certain amount of capital to the manager (mudhorib) with a profit sharing agreement. This form confirms the collaboration with $100 \%$ capital contribution from ShahibulMaal and the expertise of Mudhorib. ${ }^{2}$

Mudharabah agreement in financing according to the explanation in paragraph 19 letter $\mathrm{c}$ of Law Number 21 Year 2008 is a contract of cooperation between a first party (shohibul mal or Islamic Bank) which provides all capital and a second party (mudhorib or Customer) acting as fund manager by dividing business profits in accordance with the agreement set forth in the contract, while the loss is borne entirely by the Islamic Bank unless the second party makes a deliberate mistake, negligence or violates the agreement..

Mudharabah financing has a considerable risk for shahibulmaal or Islamic banking. Therefore, the regulation in Indonesia mandates that the Islamic Banking to activate the supervisory function of customers. This matter is regulated in Bank Indonesia Circular Number 10/14 / DPbS which contains as follows: "The Bank has the right to supervise and foster the business of the customer even though he does not participate in managing the customer's business. The right is that the Bank can review and request evidence from the customer's business report based on supporting evidence that can be accounted for. "Furthermore, this matter has been regulated in Article 38 Paragraph 1 of Act Number 21 of 2008 which contains the following:" Bank Islamic and Islamic Business Units are required to apply risk management, the principle of knowing customers, and customer protection". Supervision of mudharabah financing Islamic banking is actually part of the risk management procedures that must be carried out by all Islamic Banking in accordance with what is stated in section 2 subsection 1 of Financial Services Authority Regulation Number 65/POJK.03/2016 which contains the following: "Banks are required implement Risk Management effectively".

${ }^{2}$ Nurul Ichsan Hasan. Perbankan Syariah (Jakarta: Referensi, 2014), 227. 


\section{Method}

This study uses an empirical juridical method. In empirical legal research, the social sciences are used to analyze and provide answers to make effective the entire legal institutional structure. ${ }^{3}$ This study studies and examines the interrelationships between law and other social institutions. ${ }^{4}$

This study uses descriptive analytical specifications. Moh Nazir explained that descriptive research studies problems in society, as well as the procedures that apply in society and certain situations, including about the relationships of activities, attitudes, views, and ongoing processes and influences from a phenomenon. ${ }^{5}$ That way, it can be known that the analytical descriptive method describes the state of the object under study and a number of factors that influence the data obtained are collected, compiled, explained, and then analyzed.

This study uses purposive sampling technique. The technique is sampling aims to be done by taking the subject based on a specific goal. This technique is usually chosen for reasons of limited time, effort and cost, so it cannot take a large and far-off sample.

\section{Result And Discussion}

\subsection{Review of Islamic Banking}

The definition of Islamic Banks according to Law Number 21 of 2008 Article 1 paragraph 7 is the banks that carry out their business activities based on Islamic Principles and according to their type consist of Islamic Commercial Banks and Islamic People's Financing Banks.WarkumSumitro ${ }^{6}$ explained that Islamic Bankis bank whose operating procedures are based on Islamic prayer procedures, namely referring to the provisions of the Qur'an and Al-Hadith.

Muhammad $^{7}$ explained that Islamic Banks are banks that operate by not relying on interest and their products are developed based on the Qur'an and the Prophet's Law. In international terms, it is often called Islamic Banking or Interest-free banking, namely financial operations and various products that are developed based on IslamicIslamic, specifically relating to the prohibition of the practices of riba (interest), maysir (speculation), and gharar (obscurity). ${ }^{8}$ Rachmadi Usman explained what is meant by Islamic banks are banks whose operations are in accordance with Islamicor sharia principles."Interms ofgoals, the sharia

\footnotetext{
${ }^{3}$ Soerjono and Abdurrahman. Metode Penelitian (Jakarta: RinekaCipta, 2005), 112.

${ }^{4}$ RonyHanitijo. Metodologi Penelitian Hukum dan Jurimetri (Jakarta: Ghalia Indonesia, 1990), 34.

${ }^{5}$ Soerjono and Abdurrahman. Metode Penelitian (Jakarta: Rineka Cipta, 2005), 21.

${ }^{6}$ WarkumSumitro. Asas-AsasPerbankan Islam (Jakarta: Rajagrafindo Persada, 2004), 5.

${ }^{7}$ Muhammad. Manajemen Bank Syariah (Yogyakarta: UPP AMP YKPN, 2005), 10.

${ }^{8}$ Rachmadi Usman. Aspek Hukum Perbankan Syariah. (Jakarta: SinarGrafika, 2012), 33.
} 
principles prioritize on thewelfareofthe people andsustainablegrowthby focusingonthereal sector.Thus,Islamicbanking has an orientation on additional value creation.Basedon thesecharacteristics, therefore thegovernance system of Islamic banking ismorecomplex thanconventionalbanks.It isbecause Islamicbanking hastopayattentiontotheregulationingeneral, it mustalsocomply withIslamicprinciples derived fromIslamic lawto be able to competeinthe market." 9 Shariafinancial industry of the total of global assets, including Islamic banking Indonesia still has the potential to be developed. ${ }^{10}$

Syafii Antonio ${ }^{11}$ explained the difference between conventional banking and bank Islamic as follows:

\begin{tabular}{|c|c|c|}
\hline No. & Conventional Bank & Islamic Bank \\
\hline 1 & $\begin{array}{l}\text { Not caring about halal factors in } \\
\text { investing }\end{array}$ & Only make halal investments \\
\hline 2 & Using debt and interest & $\begin{array}{l}\text { Based on the principle of profit sharing, buying } \\
\text { and selling, or rent. }\end{array}$ \\
\hline 3 & Only profit oriented & Profit and religious oriented \\
\hline 4 & $\begin{array}{l}\text { Relationships with customers in the form } \\
\text { of debtor-creditor relationships. }\end{array}$ & $\begin{array}{l}\text { Relationships with customers in the form of } \\
\text { partnership relationships. }\end{array}$ \\
\hline 5 & There is no similar council. & $\begin{array}{l}\text { The collection and distribution of funds must } \\
\text { be in accordance with the fatwa of the Islamic } \\
\text { Supervisory Board. }\end{array}$ \\
\hline
\end{tabular}

The development of Islamic banks in Indonesia has always increased despite has a slow growth. Islamic banks in Indonesia hold a market share of $4.81 \%$ with asset growth reaching 11.9 7\% as of June 2016. Globally, together with Qatar, Saudi Arabia, Malaysia, the United Arab Emirates and Turkey, Indonesia is considered as a financial Islamic driving force in the future front. Contribute $3 \%$ of total global assets. Therefore, Indonesian Islamic banking still has the potential to be developed. ${ }^{12}$

\footnotetext{
${ }^{9}$ Frederick V. Perry, The Corporate Governance of Islamic Banks: A Better Way of Doing Business, Michigan State Journal of International Law, Vol.19:2,2011,p. 26

${ }^{10}$ Habib Ahmed, Islamic Law, Adaptability and Financial Development, Islamic Economic Studies Vol. 13, No. 2, February 2006, p. 5.

${ }^{11}$ Syafi'i Antonio. Bank Syariah dari Teori ke Praktek, (Jakarta: GemaInsani, 2001), p. 34.

${ }^{12}$ Ro'fah Setyowati et al, "Sharia Governance on Islamic Banking: Spiritual Rights Perspective on Consumer Protection in Indonesia", Diponegoro Law Review Vol 2 No 1, (April 2017): 2.
} 


\subsection{Review of Mudharabah Financing}

In the Musnad Imam Shafi'i explained that Al-Qiradh derived from the word al-qardh, meaning to cut. This is because the owner of the property deducts part of the profits managed by the borrower. This is also called the term mudharabah and muqorodhah. ${ }^{13}$

While IbnuRushd in the book BidayatulMujtahid explained that what is meant by Al-Qiradh (mudharabah) is if someone hands over property to another person to use in a trading business, where the party working has the right to obtain a certain portion of the profit. That is the part that was agreed upon by both parties: one third, one quarter or half. ${ }^{14}$

SayyidSabiq in the book of SunnahFiqh explains about Al-Qiradh (mudaraba) is a contract between both parties for one of them to issue a sum of money to another party to be traded. And profit is divided into two according to the agreement. ${ }^{15}$

In the Compilation of Islamic Economic Law, it is stated in section 20 subsection 4 that: "Mudharabah is a collaboration between the owner of the fund or the investor with the capital manager to do certain business with profit sharing based on the ratio." Whereas in Fatwa DSN MUI No. 07/DSN-MUI/IV/2000, mudharabah is a financing channeled by Islamic Financial Institutions to other parties for a productive business.

Syafi'i Antonio ${ }^{16}$ explained that Mudharabah comes from the word dharb, meaning to hit or walk. The definition of hitting or walking is more precisely the process of someone hitting his foot in running a business. Ascarya explained that briefly mudaraba or investment is the surrender of money capital to people who trade so that he gets a percentage of profits.

\subsection{Review of Islamic Banking Financing Supervision.}

The development of Islamic banking in Indonesia is so fast. However, there is still an assumption from the public that Islamic banks are conventional banks that run their operations using the term Islam to lure the Muslim community. For example, a contract that starts the sentence Bismillahirrahmaanirrahiim and workers who wear Muslim clothes. However, the implementation of the agreement on Islamic banks still uses methods prohibited by Islamic law. Therefore, it is not surprising that at the beginning of the establishment of Islamic banks, many did not believe in

\footnotetext{
${ }^{13}$ M Abid As-Sindi. Musnad Imam Syafi'i(Bandung: Sinar Baru Algesindo, 1996), 1357.

${ }^{14}$ IbnuRusyd. Tarjamah Bidayatul Mujtahid Volume 3 (Semarang: Asy-Syifa, 1990), 233.

${ }^{15}$ Sayyid Sabiq. Fikih Sunnah Volume 13 (Bandung: Alma'arif, 1987), 31.

${ }^{16}$ Syafi'i Antonio. Bank Syariah dari Teori ke Praktek , (Jakarta: Gema Insani, 2001), 95.
} 
the success of Islamic economists in consolidating banking institutions with Islamic law. ${ }^{17}$ To overcome this, a system that can oversee Islamic banks is needed to always carry out its operations in accordance with Islamic law.

One of the important activities in the financing process is financing monitoring or monitoring which is a series of activities to find out and monitor the development of the financing process, financing trips, and business development since financing is provided until paid off. ${ }^{18}$

According to Veitzhal Rifai, ${ }^{19}$ financing supervision is an attempt to control the implementation of financing, so that the assumed requirements and targets can be met as a basis for financing agreements. That way, supervision of financing can be interpreted as one of the functions of management that seeks to safeguard and secure the financing as wealth, and can know the terms of lending and assumptions as the basis for financing agreements reached or deviations occur.

Further financing supervision has been clearly stated in Bank Indonesia Regulation Number 7/46 / PBI / 2005 article 6 letter C stating that: Banks do not participate in the management of the customer's business but have the right to supervise and foster customer business;

The purpose of financing supervision, consisting of ${ }^{20}$ :

a. The wealth of Islamic banks will always be monitored and avoid any misuse of individuals from outside or from within Islamic banks;

b. To ensure the accuracy and correctness of administrative data in the financing sector;

c. To promote efficiency in loan management and set targets;

d. Financing management policies will be more obeyed.

Meanwhile, according to Veithzal rivai, the purpose of financing supervision is as follows:

a. Become a system and provisions as the basis for financial operations that can be carried out to the maximum extent possible;

b. The safeguarding and security of financing as wealth must be managed properly, so that no risk arises due to deviations, both by the debtor and by the internal company;

\footnotetext{
${ }^{17}$ Bagya Agung Prabowo and Jasri Jamal, "Concept and Application of Akad Wakalah in Murabaha Financing in Islamic Banking (A Comparative Study Between Indonesia And Malaysia)” Diponegoro Law Review Vol 2 No 1 (April 2017): 2. p. 1-14.

${ }^{18}$ IkatanBankir Indonesia. Memahami Bisnis Bank Syariah (Jakarta: Gramedia, 2014), 233.

${ }^{19}$ VeithzalRivai. Islamic Financial Management (Jakarta: RajagrafindoPersada, 2008), 488.

${ }^{20}$ Muhammad, Manajemen Bank Syariah, (Yogyakarta: UPP AMP YKPN, 2005), 310.
} 
c. Financing administration and documentation must be carried out in accordance with the provisions stipulated so that accuracy, completeness, authenticity, and accuracy can be information for every line of management involved in financing;

d. Improve effectiveness and efficiency in each stage of financing so that financial planning can be implemented properly;

e. Portfolio development can be done so that it has productive asset quality and supports the creation of banks that are not problematic.

The five objectives of financing supervision above are related to each other. For example, financing administration that is managed well, thoroughly, and correctly will help and facilitate finding deviations that occur. In addition, well-documented financial records will improve the efficiency and effectiveness of financing management.

The financing supervision function ${ }^{21}$ includes at least the following:

a. Monitoring the distribution of funds. Supervising the provision of financing has met the principles of prudence and sharia principles;

b. Supervision of collectability assessment. Overseeing the assessment of the collectibility of fund distribution in accordance with the provisions set by Bank Indonesia;

c. Coaching to customers for channeling funds. The Bank conducts guidance to its customers by, among others, making visits to customers. Secondly, the bank will provide guidance in terms of administration and management so that the quality of the distribution of funds remains good. For customers who have the potential to be problematic, the bank must provide a warning;

d. Monitor document administration. Monitor the implementation of the administration of fund distribution documents to comply with the applicable regulations;

e. Monitor the adequacy of the allowance for the elimination of funds disbursement;

The implementation of this supervisory function is the responsibility of each level of management or every individual who manages activities in the field of financing at each bank or branch. Thus, essentially the financing supervision activities are "inherent" in each organizational unit and existing work procedures that are managed by each level of management / individual. While the supervisory function carried out by the external supervision unit or other internal

${ }^{21}$ Muhammad, Sistem dan Prosedur Operasional Bank Syariah, (Yogyakarta: UII Pres, 2000), 150. 
auditors is as a means of re-checking and dynamiting whether the internal control in the financing sector has been running properly. ${ }^{22}$

The principle of financing supervision is:

a. Early prevention of loss of fund distribution. The supervisory function must be preceded by early prevention efforts on matters that can harm the bank by avoiding the practice of giving funds that are not healthy funds, by conducting an accurate and objective analysis;

b. Supervision of the distribution of funds. Every bank official, especially those related to fund disbursement, must carry out continuous supervision on every implementation of the distribution of funds;

c. Internal audit of fund distribution. Supervision of the distribution of funds must also be complemented by an internal audit of all aspects of fund disbursement carried out by authorized officials.

\subsection{The Concept and Mechanism for Supervising Mudharabah Financing InIslamic Banking.}

Financing supervision is carried out through several monitoring activities ${ }^{23}$, namely:

1) On Desk, namely by doing:

a. Verification of customer financing documents related to financing requirements

b. Research and verification of deficiencies found.

c. Identification of potential problems in cash generation.

2) On Site, namely by doing:

a. Physical location visits, to see conditions in the field that include business aspects, guarantee project progress, detect customer problems in running the business, assess customer management capabilities, and other things needed to be physically checked.

b. Trade Checking, to see the condition of the business of the financing customer by utilizing information from suppliers, distributors, competitors, industry associations, or other business partners.

\footnotetext{
${ }^{22}$ Veithzal Rivai, Islamic Financial Management, (Jakarta: Rajagrafindo Persada, 2008), 489.

${ }^{23}$ Muhammah. Sistem dan Prosedur Operasional Bank Syariah (Yogyakarta: UII Pres, 2000), 164.
} 
c. Credit checking, to monitor financing by utilizing information relating to the smoothness of accounts payable, both for facilities provided by the concerned bank and other banks.

3) Early Warning Signal, in the form of early monitoring actions for financing current collectability and special attention. This process aims to provide an early warning signal for symptoms that can affect the level of collectability of customers so that preventive actions can be taken immediately to prevent a decrease in collectability.

4) Annual Review Financing is a process of reviewing annual financing before the maturity of the financing. The Bank will determine the continuation of financing, whether the financing can be extended or must be repaid.

\subsection{Analysis of the Importance of Mudharabah Financing Supervision.}

Financing with the mudharabah principle is a type of financing with profit sharing transactions based on the product using the profit sharing principle in profit sharing. Profit sharing transactions can also be referred to as equity financing or financing in which the profit sharing is based on fairness between the customer and the bank. Justice is reflected in the principle of profit and loss sharing, losses are shared and profits are shared. ${ }^{24}$

The important thing in the mudharabah financing process is this process is not a debt agreement. The relationship between the Islamic banks as shahibulmaal and the financing customers as mudarib is a cooperative relationship. So that the position is equally strong and equal.

Mudharabah financing agreement is a cooperation agreement. The relationship between the Islamic bank and the customer is not the relationship between the debtor and the creditor but the relationship of the business partner. Therefore, actually when a customer as a mudarib experiences a loss in running his business, the loss must be borne jointly by the Islamic bank and the customer. So that the mechanism is in accordance with the principle of profit sharing.

The next reason is to ensure that the financing is used to run the business according to the contract that has been agreed between the Islamic bank and the customer as well as shutting down that the business carried out does not conflict with Islamic values. When customers get financing, there will be an opportunity for customers to do moral hazard in the form of irregularities in using the funds. This will risk making the customer's business become a big risk so that it has an impact

\footnotetext{
${ }^{24}$ Ahmad Dahlan. Bank Syariah (Yogyakarta: Teras, 2012), 164.
} 
on the risk carried out by Islamic banks. This is because the principle used in mudharabah financing is the principle of profit sharing.

With supervision of mudharabah financing, it will reduce the likelihood that customers will conduct fictitious businesses. With the on-site visit, the Islamic bank will really know the sustainability of the customer's business. In addition, Islamic banks can also ensure that the business carried out is a business that is not contrary to Islamic principles. One of the pillars of mudharabah is that the business carried out is a lawful business.

The relationship between Islamic banks and customers is a cooperative relationship. Therefore, both parties should help each other to achieve a successful business and not experience significant damage. Financing supervision can also be a means for Islamic banks as experts in finance to provide advice to customers in conducting their business. That way, customers will be more careful in running their business. The relationship between Islamic banks and customers will become even tighter. When customers experience profits, Islamic banks will also experience profits.

\subsection{Analysis on Regulation of Islamic Banking Mudharabah Financing Supervision in Indonesia.}

The regulations governing supervision of mudharabah financing are now regulated in Bank Indonesia Regulation Number 7/46/PBI/2005 section 6 subsection C which states that: "Banks do not participate in managing the customer's business but have the right to supervise and foster customer business"

According to the regulation, it is known that supervision and fostering of business customers is a right for Islamic banks. Therefore, Islamic banks will not get any sanctions if they do not carry out the supervision function of the financing properly. This is because bank supervision of financing is the right of Islamic banks, not obligations, so it is free to do or not do.

Whereas, that financing supervision is a very important thing to prevent the occurrence of damage on the part of the customer. It should be remembered that the relationship between Islamic banks as shahibulmaal and financing customers as mudarib is not a relationship between debtors and creditors. So that Islamic banks should also make efforts to ensure that customers do not fall into losses. 
In addition, in Bank Indonesia Regulation Number 7/46/PBI/2005 section 6 subsection C is still very minimal regarding the procedures for supervision of financing that should be. So that Islamic banks do not have a clear legal basis in doing so.

If the regulations governing financing supervision are still very general and very elastic as they are now, then this could be the reason that Islamic banks do not supervise financing seriously. Islamic banks will give reasons that the existing legal basis does not regulate. In addition, it could be because of the weakness of the existing legal basis, customers are also reluctant to be monitored by Islamic banks. The reason for feeling uncomfortable may be expressed by the customer.

Indeed, regulations concerning supervision of financing have also been regulated in Bank Indonesia Circular Number 10/14 / DPbS concerning the implementation of Islamic Principles in Fund Collection Activities and Fund Distribution as well as Islamic Bank Services that explain as follows: "The Bank has the right in business supervision and guidance Even though the customer does not participate in the management of the customer's business, the Bank may, among other things, review and request evidence from the customer's business report based on reliable supporting evidence;"

Based on this regulation, the regulation regarding financing supervision has been arranged in more detail. This is done by reviewing and requesting evidence from the customer's business report based on supporting evidence that can be accounted for. However, there is no description of the procedure for conducting the review, how and how to find the evidence of the results of the business report. So that it still leaves huge gaps to not supervise financing properly.

In addition, Bank Indonesia Circular Number 10/14/DPbS concerning the implementation of Islamic Principles in Funds Collection and Distribution of Funds and Islamic Bank Services still states that financing supervision is the right of Islamic banks. When financing supervision is still a right for Islamic banks, Islamic banks will not get any sanctions if they do not. Conversely, even customers can easily refuse to be monitored by Islamic banks.

Making more detailed regulations regarding supervision of mudharabah financing is very necessary to provide legal certainty for the Islamic financial industry players, especially the world of Islamic. Whereas if the provisions concerning supervision of mudharabah financing are only poured in the contract, then there will be disparity between Islamic banks. So that it is susceptible to causing irregularities regarding the procedures for financing supervision as has happened now.

Many Islamic banks ultimately do not supervise financing seriously for two reasons. The first is because supervising mudharabah financing requires quite a lot of human resources, so that it will also incur substantial costs for Islamic banks. Secondly, Islamic banks will be afraid that if 
they supervise strict financing it will make customers reluctant to apply for financing to the Islamic bank. As a result, customers prefer Islamic banks that are not too strict in carrying out their supervisory functions.

\section{Conclusion}

The concept and mechanism for financing supervision based on Bank Indonesia Circular Number 10/14/DPBS is to review and request evidence of the customer's business report. As according to various literatures at least found that the procedures for supervision of financing is by on site and on desk.

This is in accordance with the reality on the ground where Islamic banks will make visits to the business premises of the financing customers and will request the customer's business financial statements. Although it was found that there were Islamic banks that had not carried out the supervision process of mudharabah financing or had supervised the supervision of mudharabah financing but had not implemented it seriously.

Mudharabah financing supervision is something that is very necessary because it can prevent the occurrence of business losses made by customers financing as mudarib. In addition, it can also provide strong evidence that losses are not due to intentions of the financing customers. Financing supervision is very important because the relationship between Islamic banks and financing customers is not a debt-debt relationship where Islamic banks as debtors and financing customers as creditors. However, in mudharabah financing the relationship between Islamic banks and financing customers is a partnership relationship where the bank as shahibulmaal and the customer as mudarib must work together where both parties must get the same risk.

When a financed business experiences profits, the customer must honestly provide benefits in accordance with the agreement with the Islamic bank. Conversely, if there is a loss that is not caused by the intentional customer then the Islamic bank must be willing to bear the loss. To be able to determine the amount of profit or loss amount from a customer, a mudharabah financing supervision process is needed. It aims to prevent the occurrence of asymmetric information and moral hazard that can give harm to one party. A function that is not less important than the supervision process of mudharabah financing is that Islamic banks can provide input to customers regarding the development of their business, thereby minimizing the occurrence of losses in the business. 
Establishment of a more detailed regulation on mudharabah financing supervision is necessary to provide a strong legal basis in the mudharbah financing supervision process. So there is no reason not to supervise mudharabah financing from both Islamic banks and financing customers. Whereas if the provisions regarding supervision of financing are only stated in the contract, there will be disparity between Islamic banks. In addition, even though the contract has been set forth in a real note so that it has strong legal force, there are still many irregularities that occur in the supervision process of mudharabah financing.

By making more detailed regulations regarding the supervision process of mudharabah financing, it will guarantee legal certainty in carrying out the supervision process of mudharabah financing. The Islamic bank has a clear reference and legal basis in carrying out the supervisory process of mudharabah financing and the customer can also understand what he has to do in supporting the supervision process of mudharabah financing.

The process of financing supervision must be carried out as effectively and efficiently as possible. Do not let the supervision process of mudharabah financing actually burden one of the parties, both Islamic banks and customers. Conversely, do not let the financing supervision process be so loose that the essence and substance of the objective of monitoring mudharabah financing is not achieved.

The establishment of regulations that regulate the supervision of more detailed mudharabah financing needs to be made immediately. This is so that the supervision process for mudharabah financing has a strong legal basis. Supervision is carried out not only by being stated in the agreement. This is because in reality many parties are reluctant to follow the contract even though it has been stated in the real note. Clarity regarding the technical details of the supervision process for mudharabah financing will provide clarity on what matters must be done by the Islamic bank as shahibul maal and the customer financing as mudharib.

\section{References}

Antonio, S. (2001).Bank Syariah dari Teori ke Praktek, Jakarta: Gema Insani.

As-Sindi, M.A. (1996) Musnad Imam Syafi'i. Bandung: Sinar Baru Algesindo.

Dahlan, A. (2012). Bank Syariah. Yogyakarta: Teras.

Frederick V. Perry, (2011), The Corporate Governance of Islamic Banks: A Better Way of Doing Business,Michigan State Journal of International Law, Vol.19:2.

HabibAhmed. (2006). Islamic Law, Adaptability and Financial Development, Islamic Economic Studies Vol. 13, No. 2. 
Hanitijo, R. (1990).Metodologi Penelitian Hukum dan Jurimetri. Jakarta: Ghalia Indonesia.

Hasan, N.I. (2014) Perbankan Syariah. Jakarta: Referensi.

IkatanBankir Indonesia. (2014).Memahami Bisnis Bank Syariah. Jakarta: Gramedia.

Muhammad. (2005).Manajemen Bank Syariah. Yogyakarta: UPP AMP YKPN.

Muhammah. (2000).Sistem dan Prosedur Operasional Bank Syariah. Yogyakarta: UII Pres.

Prabowo, B.A., Jasri, J. (2017). Concept and Application of Akad Wakalah in Murabaha Financing in Islamic Banking (A Comparative Study between Indonesia and Malaysia). Diponegoro Law Review Vol 2 No 1.

Rivai, V. (2008). Islamic Financial Management. Jakarta: Rajagrafindo Persada.

Rusyd, I. (1990).Tarjamah Bidayatul Mujtahid Volume 3.Semarang: Asy-Syifa.

Sabiq, S. (1987).Fikih Sunnah Volume 13.Bandung: Alma'arif.

Setyowati, R., Abubakar, L., Rodliah N. (2017). Sharia Governance on Islamic Banking: Spiritual Rights Perspective on Consumer Protection in Indonesia. Diponegoro Law Review Vol 2 No 1.

Soerjono and Abdurrahman. (2005)Metode Penelitian. Jakarta: Rineka Cipta.

Sumitro, W. (2004). Asas-Asas Perbankan Islam.Jakarta: Rajagrafindo Persada.

Usman, R. (2009) Produk dan Akad Perbankan Syariah di Indonesia. Bandung: Citra Aditya Bakti.

Usman, R. (2012).Aspek Hukum Perbankan Syariah. Jakarta: Sinar Grafika. 